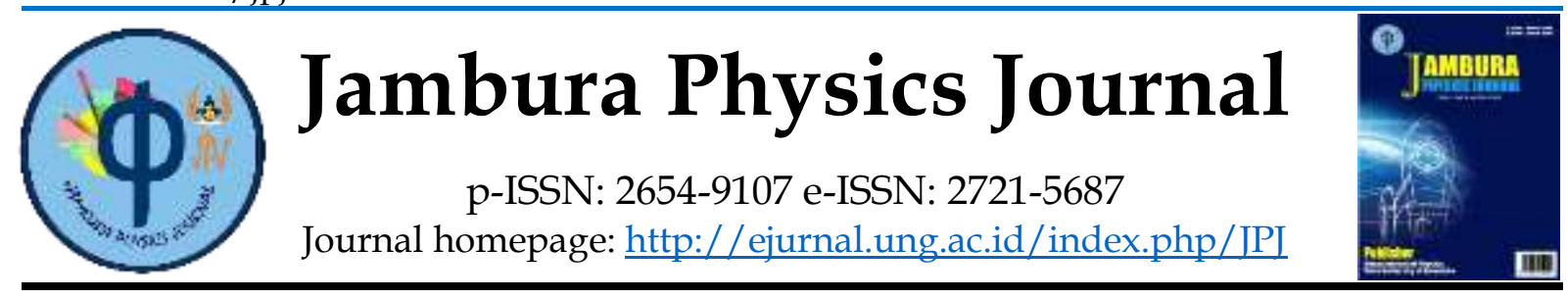

\title{
PENERAPAN PEMBELAJARAN BERBASIS KEARIFAN LOKAL TERHADAP PENINGKATAN KETERAMPILAN PROSES SAINS SISWA
}

\author{
Tirtawaty Abdjul ${ }^{1 *}$, Nancy Katili ${ }^{1}$ \\ ${ }^{1}$ Prodi Pend. IPA Jurusan Fisika Fakultas Matematika dan Ilmu Pengetahuan Alam Universitas Negeri \\ Gorontalo. Jl. Prof. Dr. Ing. B. J. Habibie Kecamatan Tilongkabila Kabupaten Bone Bolango 96554, \\ Indonesia
}

*Email: tirtawaty@ung.ac.id

Received: 07 July 2021. Accepted: 30 September 2021. Published: 29 October 2021

ARTICLE INFO
Keywords:
Lokal Wisdom; Science
Process Skills
How to cite:
Abdjul, T. \& Katili, N.
(2021). Penerapan
Pembelajaran Berbasis
Kearifan Lokal Terhadap
Peningkatan Keterampilan
Proses Sains Siswa.
Jambura Physics Journal,
3(2), 114-121
DoI:
https:/ / doi.org/10.34312/
jpj.v3i2.11166

\begin{abstract}
This study aims to see the effect of applying local wisdom-based learning on science process skills in class XI high school heat concept. The method in this study is an experimental method with the type of Pre-Experimental Design. This research belongs to the type of quantitative descriptive research with the research design of One-Group Pretest-Posttest Design. The research was conducted in the Odd Semester of the 2019/2020 Academic Year in class XIA students of SMA Negeri 1 Paguat with a total of 20 students. Based on the results of the research, it was found that the average results of students' science process skills when given a pre-test was 15.44 (very poor) and when given a post-test it was 92.01 (very good). The results of the N-Gain test analysis were obtained for indicators of observing, classifying, communicating and drawing conclusions to get an average of 0.87 (high category). Based on the results of research that has been carried out by researchers and other researchers, it can be concluded that learning based on local wisdom affects the science process skills of class XI students of SMA Negeri 1 Paguwat in learning physics, especially on the concept of heat.
\end{abstract}

\section{Pendahuluan}

Pilar utama sebagai penentu kemajuan suatu bangsa yang termanifestasi pada kualitas sumber daya manusia yang cerdas, berkarakter, berakhlak mulia, kreatif, inovatif, dan berdaya saing adalah definisi dari pendidikan.Pemberian kewenangan yang lebih besar kepada pemerintah daerah oleh pemerintah Indonesia dibidang pendidikan untuk membuat kebijakan dan melaksanakan kebijakan tersebut 
Abdjul, T \& Katili, N/ Jambura Physics Journal (2021) Vol. 3(2): 112-119

membuat tiap daerah setempatbisa mengembangkan potensi dan juga budaya yang terdapat pada masing-masing daerah.Berkaitan dengan hal ini maka pendidikan berbasis kearifan lokal menjadi suatu kebijakan yang bisa dikembangkan pada suatu lembaga pendidikan.Berbagai potensi yang dimiliki oleh tiap-tiap daerah bisa berkembang dengan adanya pendidikan berbasis kearifan lokal juga tidak menutup kemungkinan s anak-anak di suatu daerah tersebut dapat mengenal budaya serta nilai-nilai daerahnya masing-masing.

Kearifan lokal adalah suatu yang menjadi identitas budaya yang dikenalkan kepada generasi muda melalui dunia pendidikan karena generasi mudah setempat itulah yang berarti mampu mempertahankan daerahnya sendiri. Kearifan lokal yang sering dijumpai dikehidupan sehari-hari peserta didik tentunya berupa objek yang bisa meningkatkan tingkat pemikiran peserta didik sehingganya bisa menerima materi yang diajarkan.Sibarani (2012) berpendapat bahwa, kearifan lokal merupakansalah-satu bentuk dari pengetahuan asli masyarakat tersebut yang asalnya dari nilai luhur budaya masyarakat setempat sehingga dapat mengatur tatanan kehidupan masyarakat. Selain itu menurut Damayanti, dkk (2013) Kearifan lokal (lokal wisdom)merupakan gagasan-gagasan setempat (lokal) yang bersifat bijaksana, penuh kearifan, bernilai baik, yang terutama dan diikuti oleh anggota masyarakatnya.

Disisi lain Abubakar (2010) berpendapat bahwa kearifan lokal sebagai kebijakan yang bersandar pada filosofi, nilai-nilai, etika, dan perilaku yang melembaga secara tradisional untuk mengelola sumber daya (alam, manusia, dan budaya) secara berkelanjutan. Kebudayaan dan nilai-nilai kearifan lokal terlihat pada sebuah nilainilai skills seperti sikap saling percaya, sikap kemampuan bekerja sama, kepercayaan (religius), tanggung jawab, solidaritas, musyawarah, kebersamaan, gotong royong, cinta tanah air, nilai kesetaraan, kepedulian, nilai kemandirian dan nilai pengetahuan (Ade \& Affandi, 2016). Hal ini terlihat pada masing-masing daerah tertentu untuk kearifan lokal memiliki nilai-nilai positif bagi perkembangan dan karakter anak sehingga dapat menumbuhkan kecintaan terhadap budaya daerah.Selain itu, melalui cerita rakyat guru dapat mengenalkan budaya nusantara kepada siswa dan dapat mengambil petuah sebagai salah satu pendidikan karakter (Sumayana, 2017).

Berdasarkan hasil penelitian yang telah dilakukan oleh Azizahwati \& Yasin (2017) kearifan lokal sebaiknya diintegrasikan dalam pembelajaran sains di sekolah.Pengintegrasian kearifan lokal menjadi sebuahalternative pemecahan masalah dalam pembelajaran, seperti penguasaan konsep dan keterampilan proses sains siswa. Hal ini menjadi penting untuk diprogramkan didunia pendidikan agar siswa menjadi aktif dalam pembelajaran, sehingga mampu mengembangkan potensi serta keterampilan yang dimiliki dlam proses pembelajaran..Keterampilan proses sains menurut Tanwil \& Liliasari (2014) merupakan proses dalam melakukan aktivitas-aktivitas sains. Karena erat hubungannya dengan persoalan-persoalan yang berkaitan dengan kehidupan sehari-hari. Hal ini berarti bahwa dengan mengajarkan keterampilan proses sains kepada siswa sama dengan mengajarkan keterampilan yang nantinya mereka terapkan dalam kehidupan sehari-hari. Keterampilan proses dapatmelibatkan keterampilan-keterampilan kognitif atau intelektual, manual serta sosial.

Indikator keterampilan proses sains menurut Warianto (2011) terdiri atas keterampilan mengamati, menafsirkan, berhipotesis, mengelompokkan, meramalkan, 
Abdjul, T \& Katili, N/ Jambura Physics Journal (2021) Vol. 3(2): 112-119

merencanakan percobaan/penelitian, mengajukan pertanyaan, menggunakan alat/bahan, menerapkan konsep, berkomunikasi, dan melaksanakan percobaan. Berdasarkan indikator tersebut di atas keterampilan yang lebih dahulu berkembang dibandingkan dengan keterampilan lainnya adalah Keterampilan observasi, interpretasi, dan klasifikasi (Suja, 2005). Keterampilan mengajukan pertanyaan, menyusun hipotesis, dan merencanakan percobaan kurang berkembang.Dngan mengerjakan soal-soal keterampilan proses sains, siswa dituntut dapat berpikir kritis dan sistematis, serta merasakan seperti melakukan percobaan sendiri. Berdasarkan penelitian yang telah dilakukan oleh Hamdiyati \& Kusnadi (2006) bahwa rata-rata kemampuan siswa pada masing-masing jenis keterampilan proses termasuk ke dalam kategori sedang, yaitu 63,10\%. Selain itu, berdasarkan hasil observasi yang telah dilakukan di sekolah SMA Negeri 1 Paguat bahwa proses pembelajaran yang berbasis kearifa lokal dan melibatkan peran siswa dalam pembelajaran fisika masih kurang optimal. Pembelajaran saat ini masih menunjukkan siswa cenderung pasif. Keterampilan proses sains siswa dalam hal mengamati, mengklasifikasi, mengkomunikasi, dan menyimpulkan masih rendah .

Keterampilan proses sains siswa pada tingkat pendidikan menengah sangat penting untukdiketahui dalam rangka mengoptimalisasikan kegiatan pembelajaran. Oleh karena itu penting bagi peneliti perlu untuk melakukan penelitian ini dalam rangka untuk meningkatkan kemampuan keterampilan proses sains, keterampilan ilmiah dan kualitas siswa pada pembelajaran fisika.

Dengan mengembangkan ketrampilan keterampilan proses, anak akan mampu menemukan dan mengembangkan sendiri fakta dan konsep serta menumbuhkan dan mengembangkan sikap dan nilai yang dituntut (Semiawan, 1986: 18). Hal ini berarti bahwa, jika keterampilan proses tidak berkembang dengan baik pada pembelajaran fisika, maka anak tidak akan dapat menemukan dan mengembangkan sendiri fakta dan konsep serta tidak mampu menumbuhkan dan mengembangkan sikap dan nilai yang dituntutnya.

Berdasarkan uraian tersebut di atas, maka sangat penting untuk melakukan penelitian ini. Penelitian ini bertujuan untuk melihat bagaimana pengaruh penerapan pembelajaran berbasis kearifan lokal terhadap keterampilan proses sains siswa di SMA Negeri 1 paguat

\section{Metode}

Metode dalam penelitian ini adalah metode eksperimen dengan jenis PreExperimental Design.Penelitian ini tergolong dalam jenis penelitian deskriptif kuantitatif dengan desain penelitian adalahOne Group Preetest-Posttest Design. Penelitian dilaksanakan pada Semester Ganjil Tahun Pembelajaran 2019/2020 pada siswa kelas XIASMA Negeri 1 Paguat dengan sejumlah 20 orang siswa. Variabel dalam penelitian ini terdiri atas varibel bebas dan variabel terikat, dimana varibel bebas adalah pembelajaran berbasis kearifan lokas dan variable terikat adalah keterampilan proses sains siswa. Data keterampilan proses sains siswa diperoleh dengan menggunakan isntrumen tes keterampilan yang terdiri atas beberapa indikator yaitu mengamati, mengklasifikasi, mengkomunikasikan dan menarik kesimpulan. Kategori dari hasil rata-rata keterampilan proses sains siswa dapat dilihat pada Tabel 1. 
Abdjul, T \& Katili, N/ Jambura Physics Journal (2021) Vol. 3(2): 112-119

Tabel 1. Kategori skor keterampilan proses sains siswa

\begin{tabular}{ll}
\hline Rentang Prestasi & Kategori \\
\hline $81 \%-100 \%$ & Sangat Baik \\
$61 \%-80 \%$ & Baik \\
$41 \%-60 \%$ & Cukup Baik \\
$21 \%-40 \%$ & Kurang \\
$0 \%-20 \%$ & Kurang Sekali \\
\hline
\end{tabular}

Sumber (Arikunto, 2010)

Untuk melihat bagaimana pengaruh penerapan pembelajaran berbasis kearifan lokal terhadap peningkatan keterampilan proses sains siswa, makapersamaan yang digunakan sebagai berikut:

$$
<\mathrm{g}>=\frac{\% \text { skorpost-\% skorepre }}{100-\% \text { skorpre }}
$$

Kriteria dari data yang diperoleh terdapat pada Tabel 2.

Tabel 2. Kriteria tingkat N-gain

\begin{tabular}{ll}
\hline \hline Nilai n-gain & Kategori \\
\hline$<\mathrm{g}>\geq 0,7$ & Tinggi \\
$<\mathrm{g}>\geq 0,3$ & Sedang \\
$<\mathrm{g}>\leq 0,3$ & Rendah \\
\hline
\end{tabular}

Sumber: (Hake, 1999)

Analisis N-Gain bertujuan mengkategorikan besarnya peningkatan keterampilan proses sains siswa.

\section{Hasil dan Pembahasan}

Data keterampilan proses sains diperoleh dengan menggunakan tes keterampilan proses sains dengan menggunakan indikator yang diambil dari Warianto (2011). Sebelum dilaksanakan pembelajaran yang berbasis kearifan lokal, siswa diberikan dulu tes (pree test) untuk melihat keterampilan sains awal siswa. Setelah dilaksanakan pembelajaran yang berbasis kearifan lokal, maka siswa kembali diberikan tes (posttest) untuk melihat bagaimana pengaruh penerapan pembelajaran tersebut terhadap keterampilan proses sains siswa. Rata-rata hasil keterampilan proses sains siswa diperoleh melalui pree test dan posttest berdasarkan penelitian yang telah dilakukan.

Berdasarkan hasil penelitian diperoleh bahwa keterampilan proses sains siswa kelas XIA SMA Negeri 1 Paguat sebelum diadakan tindakan dan setelah diadakan tindakan yang diterapkan dengan pembelajaran yang berbasis kearifan lokal konsep Kalor terlihat pada Tabel 3 terlihat bahwa terjadi peningkatan keterampilan proses sains siswa mengalami peningkatan setelah diterapkan pembelajaran yang berbasis kearifan lokal pada konsep kalor baik pada indikator mengamati, mengklasifikasi, mengkomunikasi dan menyimpulkan. Berdasarkan analisis uji N-gain, ke empat indikator keterampilan proses sains tersebut berkategori tinggi. 
Abdjul, T \& Katili, N/ Jambura Physics Journal (2021) Vol. 3(2): 112-119

Tabel 3. Rata-rata hasil keterampilan proses sains siswa berbasis kearifan lokal pada konsep kalor.

\begin{tabular}{lllll}
\hline \multirow{2}{*}{$\begin{array}{l}\text { Indikator keterampilan } \\
\text { proses }\end{array}$} & \multicolumn{2}{c}{ Persentasi rata-rata } & \multirow{2}{*}{ Uji N gain } & \multirow{2}{*}{ Kategori } \\
\cline { 2 - 3 } Pree test & Post test & & \\
\hline Mengamati & 19.50 & 96.00 & 0.95 & Tinggi \\
Mengklasifikasi & 20.00 & 95.00 & 0.74 & Tinggi \\
Mengkomunikasi & 1.25 & 79.06 & 0.79 & Tinggi \\
Menyimpulkan & 21.00 & 98.00 & 0.97 & Tinggi \\
\hline
\end{tabular}

Perolehan rata-rata capaian hasil keterampilan proses sains siswa pada saat preetest dan post posttest dapat dilihat pada gambar 1. Berdasarkan gambar 1 terlihat bahwa pada saat diberikan test awal, capaian rata-rata capaian hasil keterampilan proses sains siswa mencapai 15,44 (berkategori sangat kurang). Setelah diterapkan pembelajaran yang berbasis kearifan lokal pada konsep kalor, hasil keterampilan proses sains siswa SMA Negeri 1 Paguat mengalami peningkatan yaitu 92,01 (berkategori sangat baik). Berdasarkan hal tersebut dapat disimpulkan bahwa pemahaman konsep siswa akan keterampilan proses sains siswa menjadi lebih baik

Tes keterampilan proses sains yang digunakan dalam penelitian ini dalam bentuk tes uraian yang terdiri dari 4 butir tes yang memuat 4 indikator yaitu indikator keterampilan mengamati, mengklasifikasi, mengkomunikasikan, dan menarik kesimpulan. Rata-rata hasil yang diperoleh siswa sebelum yang diterapkan pembelajaran yang berbasis kearifan lokal (pre-test) sebesar 15,44 atau berkategori sangat kurang. Hal ini menunjukkan bahwa pengetahuan awal siswa untuk keterampilan mengamati, mengelompokkan, mengkomunikasi dan menarik kesimpulan masih sangat kurang.Setelah diterapkan pembelajaran yang berbasis kearifan lokal, terjadi peningkatan. Hal ini terlihat dari rata-rata hasil keterampilan proses sains siswa pada saat diberikan tes akhir (post-test) mencapai 92,01 (kategori sangat baik).Berdasarkan analisis uji $\mathrm{N}$-Gain diperoleh untuk indikator mengamati, mengelompokkan, mengkomunikasi dan menarik kesimpulan mencapai nilai 0,87 atau berkategori tinggi.

Dari keempat indikator keterampilan proses, peningkatan yang paling signifikan terlihat pada pada indikator keterampilan mengkomunikasikan. Hal ini dikarenakan pada saat pembelajaran yang berbasis kearifan lokal, siswa dituntut untuk

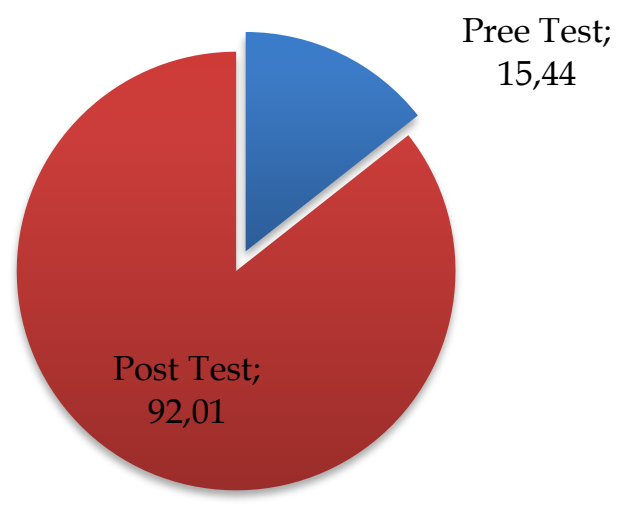

Gambar 1. Rata-rata hasil keterampilan proses sains siswa pada nilai pree test dan post test 
Abdjul, T \& Katili, N/ Jambura Physics Journal (2021) Vol. 3(2): 112-119

mengetahui dan merancang sendiri bagaimana prosedur pemecahan masalah melalui eksperimen yang telah dilakukan.Pada indikator keterampilan mengamati sebelum diberikan perlakuan, siswa cenderung menjawab berdasarkan pengetahuan awal mereka yang diperoleh dari pemahaman masyarakat daerah pesisir pantai terhadap konsep kalor. Namun setelah diterapkan pembelajaran yang berbasis kearifan lokal, pada saat diberikan tes akhir, sebagian besar siswa sudah mampu menjawab dengan benar hubungan antara konsep fisika dengan pemahaman masyarakat di daerah pesisir pantai tentang peristiwa terjadinya angin darat dan angin laut dengan menggunakan konsep kalor setelah melakukan kegiatan pengamatan lewat gambar yang diberikan. Hal yang sama juga ditemukan pada butir soal dari indikator keterampilan mengelompokkan.Sebelum diberi perlakuan, beberapa siswa dapat menjawab walaupun masih ada keraguan dalam menentukan contoh tiga cara perpindahan kalor yang terjadi dalam kehidupan sehari-hari.

Pada indikator keterampilan mengkomunikasikan sebelum diberi perlakuan, sebagian besar siswa tidak dapat menjawab. Hal ini dikarenakan masih ada keraguan dalam menentukan rumusan masalah, tujuan, alat dan bahan serta prosedur kerjanya. Namun setelah diberikan perlakuan, sebagian besar siswa sudah mampu menjawab hampir sempurna dalam menyelesaikan masalah yang berupa soal penyelidikan. Hal ini sama juga pada indikator keterampilan menarik kesimpulan. Peningkatan keterampilan proses sains sains siswa terjadi setelah diterapkan pembelajaran yang berbasis kearifan lokal. Penguasaan materi oleh siswa terjadikarena materi ajar yang diintegrasikan kedalam kehidupan sehari-hari.Karena apa yang mereka temui dalam kehidupan sehari-hari mudah dipahami dan mudah untuk dilakukan, sehinggamereka mudah mengingat akan hal yang dipelajarinya. Hal ini sejalan dengan penelitian Ekene dan Ifeoma (2011), serta Nuayi dan Very (2020), bahwa keterampilan proses sains dikembangkan melalui pengalaman langsung sehingga melibatkan penggunaan berbagai material maupun tindakan fisik.

Pengembangan keterampilan proses sains yang diterapkan dalam pembelajaran dapat membantu siswa untuk memperoleh pemahaman materi yang lebih bersifat long term memory (Abungu, dkk, 2014). Dengan menguhubungkan sains dalam kehidupan sehari-hari dapat memudahkan guru untuk menjelaskan informasi kepada siswa dalam pembelajaran(Castagno dkk.,, 2017). Hal ini didukung oleh pendapat Ibrahim yang dikutip oleh Satriawan \& Rosmiati (2016) bahwa integrasi kearifan lokal dalam pembelajaran sangat berpotensi untuk melahirkan suatu inovasi dengan kebaharuan. Pengintegrasian kearifan lokal dalam pembelajaran dapat dilakukan dengan berbagai bentuk dan tujuan, seperti memberikan inspirasi, untuk memunculkan ide-ide baru di dalam pembelajaran dan efektif dalam proses pembelajaran (Oktaviana, dkk., 2017).

\section{Kesimpulan}

Keterampilan proses sains siswa pada indikator mengamati, mengklasifikasi, mengkomunikasi dan menyimpulkan mengalami peningkatan dari sebelum diterapkan pembelajaran berbasis kearifan lokal. Indikator menyimpulkan lebih besar peningkatannya dibandingkan dengan indikator lainnya dengan perolehan nilai uji N-Gain 0,97. Rata-rata perolehan keterampilan proses sains siswa (mengamati, mengklasifikasi, mengkomunikasi dan menyimpulkan) pada saat diberikan pree-test 
Abdjul, T \& Katili, N/ Jambura Physics Journal (2021) Vol. 3(2): 112-119

sebesar 15,44(kategori sangat kurang) dan diberikan post-tess, hasil keterampilan proses sains siswa mencapai 92,01 (kategori sangat baik). Berdasarkan analisis uji $\mathrm{N}$ Gain diperoleh untuk indikator mengamati, mengelompokkan, mengkomunikasi dan menarik kesimpulan mencapai nilai 0,87 atau berkategori tinggi. Hal ini berarti bahwa penerapan pembelajaran berbasis kearifan lokal berpengaruh terhadap keterampilan proses sains siswa kelas XI SMA Negeri 1 paguat pada konsep kalor.

\section{Referensi}

Abubakar. 2010. Analisis Pengaruh Customer Satisfaction, Switching Cost, Dan Trust In Brand Terhadap Customer Retention. Jurnal Ekonomi Manajemen. Universitas Diponegoro. Semarang.

Abungu, H,E., Okere, M.I.O., \& Wachanga, S.M. (2014). The Effect of Science Process Skills Teaching Approach on Secondary School Students' Achievement in Chemistry in Nyando District, Kenya. Journal of Educational and Social Research, 4(6): 359-372.

Arikunto, S. 2010. Prosedur Penelitian Suatu Pendekatan Praktik. Jakarta: Rineka Cipta.

Azizahwati, Yasin, R. M.. 2017. "Pengembangan Lembar Kerja Siswa Berbasis Kearifan Lokal.” Jurnal Geliga Sains 5(1):65-69.

Conny, S. dkk. 1992. Pendekatan Keterampilan Proses. Jakarta: Rineka Cipta.

Damayanti, C. dkk. 2013. Pengembangan Cd Pembelajaran Berbasis Kearifan Lokal Tema Getaran dan Gelombang Untuk Siswa SMP Kelas VIII. E-Journal Universitas Negeri Semarang. ISSN: 2252-6609. 2(2): 2013

Ekene, Igboegwu. (2011). Effects Of Co-Operative Learning Strategy And Demonstration Method On Acquisition Of Science Process Skills By Chemistry Students Of Different Levels Of Scientific Literacy. Journal of research and Development. 3(1): 204-212.

Hamdiyati, Y., Kusnadi. 2006. Profil Keterampilan Proses Sains Mahasiswa Melalui Pembelajaran Berbasis Kerja Ilmiah Pada Matakuliah Mikrobiologi. Bandung: UPI.

Hake, R. R. 1999.Hake, R Richard. Hake, R Richard, (Division D), 1-4.

Nuayi, A.W., Very. (2020). Implementasi Model Pembelajaran Guided Inquiri untuk Meningkatkan Keterampilan Proses Sains dan Hasil Pengetahuan Kognitif Siswa. Jurnal Luminous: Riset Ilmiah Pendidikan Fisika, 1(2), 1-7

Oktaviana, D., Hartini, S., \& Misbah, M. (2017). Pengembangan Modul Fisika Berintegrasi Kearifan Lokal Membuat Minyak Lala Untuk Melatih Karakter Sanggam. Berkala Ilmiah Pendidikan Fisika, 5(3), 272-285.

Risamasu, P. V. M. (2016). Peran Pendekatan Keterampilan Proses Sains Dalam Pembelajaran IPA. Prosiding Seminar Nasional Pendidikan 73-81. 
Abdjul, T \& Katili, N/ Jambura Physics Journal (2021) Vol. 3(2): 112-119

Satriawan, M., Rosmiati. (2016). Pengembangan Bahan Ajar Fisika Berbasis Kontekstual Dengan Mengintegrasikan Kearifan Lokal Untuk Meningkatkan Pemahaman Konsep Fisika Pada Mahasiswa. Pendidikan Sains Pascasarjana Universitas Negeri Surabaya ISSN: 2089-1776 6(1):12 12-17.

Sibarani, Robert. (2012). Kearifan lokal: Hakikat, Peran, dan Metode Tradisi Lisan. Jakarta: Asosiasi Tradisi Lisan.

Sumayana, Y.. (2017). Pembelajaran Sastra Di Sekolah Dasar Berbasis Kearifan Lokal (Cerita Rakyat). Volume 4 Nomor 1 April 2017 ISSN 2355-5343

Suja, I. W. (2005). Profil Kompetensi Keterampilan Proses Sains Siswa Sekolah Dasar Di Kecamatan Buleleng. Singaraja: IKIP Negeri Singaraja.

Tanwil, M \& Liliasari. (2014). Keterampilan-Keterampilan Sains dan Implementasinya dalam Pembelajaran IPA. Makasar: Badan Penerbit UNM

Verawati, A., Idrus, A.. 2016. Implementasi Nilai-nilai Kearifan lokal. JPIS, Jurnal Pendidikan Ilmu Sosial, Vol. 25, No. 1, Edisi Juni 2016.Universitas Pendidikan Indonesia.

Warianto. (2011). Keterampilan Proses Sains. Jakarta: Kencana Prenada Media Group. 